\title{
THREATS TO JOURNALISTS IN SINDH: EVENTS AND PERCEPTIONS
} (2000-2017)

Fazal Hussain*

Auj-e-Kamal $^{* *}$

\begin{abstract}
This study explores threats to journalists in Sindh, searching the journalist's community, allocating its existence through a premeditated survey with directional questionnaire. Consulting 150 journalists to find out the essence, magnitude and targeting aspects of the threats they are facing in wake of their line of duty. Journalists and threats are both enter-linked since the birth of journalism, a journalist is a Watch-Dog or Gate-Keeper, who guards the boundaries of transparency, freedom of expression, sphere of laws and protects and promotes the social values and norms and facilitates political communication to educate and update the citizens. Doing all this in a part of the state where the situation of law and order is deteriorated, the population is heterogeneous in its nature, is a big challenge. Attacks on journalists have been searched from the history of media landscape for last 17 years in Sindh to weigh up the threats to Watch-Dogs. The study generalizes, whether working journalists are serving under pressure in an environment governed by threats or they feel safe and free to perform their journalistic duties. It also calculates the responses of the affected journalists in the outward appearance of complaints they file in connection with the threats faced for their professional work.
\end{abstract}

Keywords: Journalist, threat, press, professionalism, freedom, Sindh

\section{Introduction}

The vernacular press entered into a new phase with new dimensions in the new state of Pakistan in 1947 but the colonial legacy remained unchanged. Dr. Zafar Iqbal sums up in his research paper "Pakistan's Press and politics in the First Decade (1947-1958)"1 and says that press had brought the spirit of Freedom Movement with it but its fate met a failure when censor was imposed on it. The first blow was seen when the address of the founder of the state Muhammad Ali Jinnah was tried by the establishment to be cut down. The daily "Dawn" and daily "Jang" came first to Sindh pioneering the press in the newly created country but the press-government relations could not developed to institute a free press to play its role for healing the democracy in the Pakistan. Political instability and despotic governments in the state from time to time also shared atrocities to confine the

* Fazal Hussain,Ph.D. Scholar, Mass-Communication Department of Mass-Communication Federal Urdu University Karachi

${ }_{*}^{* *}$ Auj-e-Kamal, Ph.D. Chairman Department of Mass-Communication Federal Urdu University Karachi

1 Iqbal, Zafar. "Pakistan's Press and Politics in First Decade (1947-1958): An analysis Structural-Functionalist Perspective." Journal of Political Studies. Accessed on December 17, 2017 from

http://pu.edu.pk/images/journal/pols/Currentissue-pdf/Press\%20in\%20the\%20First\%20Decade.pdf 
press. K.B Saeed marks out the faction's wars in the ruling parties, palace intrigues and intolerance for truth to hear and affirms them to be the main factors, imprison the press ${ }^{2}$.

Journalists have always remained under pressure for favouritism in the country including the province of Sindh. Yusuf and Shoemaker in their research for BBC Policy Briefing ${ }^{3}$ declare that media in Pakistan remains vulnerable amid on-going threats to media professionals and the limitations imposed by the industry's financial model, which must rely heavily on adverting revenue. The state actors, government, military intelligence agencies, judiciary, and non-state actors, militant groups and political activists exploit this vulnerability. According to an online report issued by Centre for Civic Education (CCE), more than three thousands of journalists are performing their professional duties in Sindh and 46 dailies, 7 weeklies, 6 fortnightlies and 53 monthly newspapers are being published in the province on regular basis and headquarters of mostly watched TV channels, Geo, $A R Y$ and Express, bureau offices of all the Cable and terrestrial channel are working under pressure in Sindh ${ }^{4}$, but still the media had a proud history of struggle for the freedom of expression and democracy ${ }^{5}$.

\section{Government-press relation and press freedom}

The government-press relation has profound effect on the freedom of press. The province of Sindh has a history of deteriorated government-press relations ${ }^{6}$ where the press remained under constant pressure. All the governments with no exception used advertisements, newsprints quota and licenses to silence the press or gain favor through them. During the period under study the province of Sindh remained under Governor Rule from October 30, 1998 to December 17, 2002. After the coup of General Parvez Musharraf (Oct 12, 1999) emergency was declared in the state and Sindh like other parts of the state suffered the despotic rule. Undeclared censorship on the Press in the province prevailed during the Musharraf's backed rule and journalists remained under direct threats given by political parties ${ }^{7}$. No measurements were taken to improve the government-press relation even after the end of Musharraf's backed Mutaheda Qaumi Movement (MQM) and Qaid-e-Azam Muslim League (QML) coalition government. The Pakistan People's Party (PPP) and Mutaheda Qaumi Movement (MQM) coalition politics tried to keep the press under pressure and to use it for vested interests. During democratic era, lists of journalists were publicly issued and they were openly threatened ${ }^{8}$.

\footnotetext{
2 Sayeed, K. B. Collapse of parliamentary democracy in Pakistan. The Middle East Journal, 389-406. 1959

${ }^{3}$ Yusuf, Huma, Emrys Schoemaker. "The media of Pakistan: Fostering inclusion in a fragile democracy." (Policy Briefing 9, 2013) 9-10.

${ }^{4}$ Window-on-Pakistani-Media. 3-6. Accessed on January 2, 2018, from http://www.civiceducation.org/wpcontent/uploads/2010/08/Window-on-Pakistani-Media.pdf.

${ }^{5}$ Munir, Imran. "The consequences of fundamentalism on Pakistani media." PhD diss., Theses (School of Communication)/Simon Fraser University, 2002. Accessed December 25, 2017. From http://summit.sfu.ca/system/files/iritems1/7508/b28167971.pdf

${ }^{6}$ Muddasir, Mirza, interview by Fazal, Hussain, 13 February 2018. Karachi Daily Jang Office, tape recording.

${ }^{7}$ Shahzeb, Khanzada, interview by Fazal, Hussain, 15 February 2018. Karachi Geo TV office, tape recording. ${ }^{8}$ Khursheed, Abbasi, interview by Fazal, Hussain, 14 February 2018. Karachi Daily Awam Office, tape recording.
} 
Press in big cities like Karachi and Hyderabad is freer than that in small towns of Sindh ${ }^{9}$ but journalists in small towns are exposed to threats and suffer more than in large cities ${ }^{10}$ because law and order situation in big cities is better than that in the small towns. Journalists face double pressure for their journalistic work in small towns, on one hand the institutions ask for filing reports while on the other hand, the interests groups threaten them and demand them not to cover specific events and news stories ${ }^{11}$.

But journalists are also involved in deteriorating the government-press relation in $\operatorname{Sindh}^{12}$. Some of the journalists use to threaten political leaders, citizens, police and other government officers for personal gains and some time they call and challenge them after filing reports ${ }^{13}$.

Non professionalism and low educational level of journalists are also responsible for weakening the press freedom situation in the province ${ }^{14}$. Electronic media is divided into political blocks. Some of the channels support Pakistan People's Party (PPP), some of them are busy to support the agenda of Pakistan Tehreek Insaf (PTI), other advocate and try to safeguard the interests of Pakistan Muslim League Nawaz (PML) ${ }^{15}$. Michael Lavarch in his research article notes that the owners of media enterprises and journalists have a range of motivations including economical self-interest and political ideology. These types of motives invariably influence the exercise of media power ${ }^{16}$ and decline the freedom of press. Such approaches of journalists and media houses corrupt the press and increase threats to journalists.

Throughout the history of media in the province, no serious effort was made to develop a healthy and realistic relation between the press and government and between the press and society and even among the component parts of the profession like among different media enterprises and between the press and journalists. At the same time no serious and continuous attempt was tried to build up professionalism in the field of journalism rather the press has been treated as an enemy or hostile entity by the power holders and tricks gamers, the state or non-state actors. As a result no strong ties could be grown for the better use of the press to enhance the standards of society, or the government and its institutions nor the standards of the profession could be boosted to objectivity and impartiality in accordance to its spirit or international values.

\footnotetext{
${ }^{9}$ Amir, Latif, interview by Fazal, Hussain, 20 February 2018. Karachi Press Club Karachi, tape recording. ${ }^{10}$ Khaliq, Chandeo, interview by Fazal, Hussain, 24 February 2018. Hyderabad Press Club Hyderabad, tape recording.

${ }^{11}$ Hamid, Shaeikh, interview by Fazal, Hussain, 24 February 2018. Hyderabad Press Club Hyderabad, tape recording.

${ }^{12}$ Tariq, Durani, interview by Fazal, Hussain 27 February 2018. Larkana Press Club Larkana, tape recording.

${ }^{13}$ Khursheed, Abbasi, interview by Fazal, Hussain, 14 February 2018. Karachi Daily Awam Office, tape recording.

${ }^{14}$ Imtiz, Khan Faran, interview by Fazal, Hussain, 15 February 2018. Karachi TV One Office, tape recording.

${ }^{15}$ A.H, Khanzada , interview by Fazal, Hussain, 18 February 2018. Karachi Neo TV Office, tape recording.

${ }^{16}$ Lavarch, M, "Free Speech, Responsible Media, Law and Liberal Democracy", More or Less Democracy \& New Media, (2012)24-49. Retrieved on February 5, 2018, from

http://www.futureleaders.com.au/book_chapters/pdf/More-or-Less/Michael_Lavarch.pdf
} 


\section{The political barons: an impatience and illogical zeal for political communication}

The political stakeholders need to mobilize the public opinion for which they use national media to effectively convey their messages to masses. This is a general practice in the world which is termed as the Political Communication but in Pakistan, the fashion of political communication is detrimental and the parties insert pressure on media for relatively more space and coverage ${ }^{17}$. The history of journalism in Sindh reveals that this trend has given way to the harassment of media persons, flaming of media houses, blazing the houses of journalists, the properties of journalists, bribing the owners and journalists and many other unfair means to influence and threaten the media for their vested interests. Amnesty International in its report affirms that powerful political actors seek to block the transmission of broadcast channels with whom they are displeased. The report further says that the parties also pressurizing individual cable operators or physically cutting the cable for vested interests to gain ${ }^{18}$.

\section{Religious powers and their influences on the press}

Religious groups influence and check the national and even international press in Pakistan for religious content. The state ideology, social and ethical layout of the state permits them to impede into everything in the country including media. Syed Abdul Siraj concludes in his research paper that the religious groups and middle classes are criticizing some of the TV channels for western orientations in their contents ${ }^{19}$. He finds that journalists do their duties according to the perceived ethics. Social and religious activists put pressure for following their designs in the news content and coverage of events ${ }^{20}$. Successive governments in the state have sought to influence privately-owned media through censorship and regulations ${ }^{21}$. The direct and indirect censorship confine the free flow of information and affect the editorial policies of newspapers and news channels ${ }^{22}$. Laws and regulation are necessary to insure check and balance but they are used always for personal interests. National media is not only subject to legal restrictions and the state agents but political backed land grabbers, traffickers and other interest groups are also constantly confining the freedom of press and threatening journalists for vested interests.

\section{Journalists are seeking self-censorship}

Amnesty International evaluates the censoring trend and its effects on the freedom of press. The report says: harassment and other abuses faced by journalists seeking to discharge their professional duties impartially have resulted in self-censorship, in order to

\footnotetext{
${ }^{17}$ Anwar, M., \& Jan, M, "Role of Media in Political Socialization: The Case of Pakistan. Dialogue" (Pakistan 2010), 5(3)

${ }^{18}$ Amnesty International, Report, 2014. Retrieved August 23, 2017, from, https://www.am nesty. org.u k /

files/pakistan_journalists_300414.pdf

${ }^{19}$ Siraj, "Critical analysis of press freedom in Pakistan", Journal of Media and Communication Studies, (2009,. $1(3), 43$.

${ }^{20}$ Muhammad, Usman, interview by Fazal, Hussain, 24 February 2018. Hyderabad Press Club Hyderabad, tape recording.

${ }^{21}$ Yusuf Huma and Shoemaker Emrys, "The Media of Pakistan" (2013). Retrieved July,23,2017 from

http://downloads.bbc.co.uk/mediaaction/pdf/bbc_media_action_pakistan_policy_briefing.pdf

${ }^{22}$ Hasan, Abbas, interview by Fazal, Hussain, 23 February 2018. Karachi Express TV Karachi, tape recording.
} 
protect themselves and that trend leads to a diminished approach to open public discourses $^{23}$.In the year 2014, Pakistan Taliban sent mails to prominent media groups, Jang, Express, Herald and others, threatening them of dire consequences and blamed them for one-sided news about Taliban. Administrations of media outlets issued directives to suspend reports critical of the militant organization and its allies. The researcher himself received the directive for being a copy-in charge in the Jang Group of Newspapers. This type of situation demands Self-Censorship, because the authorities do fail to provide protection for journalists and media houses. Self-censorship is the only way of self-defense for journalists to continue their jobs because objectivity bear threats whereas journalists are exposed to pressure and threats ${ }^{24}$

\section{Attacks on journalists in Sindh: an overview (2000-2017)}

The police and law-enforcement agencies continued to curtail the freedom of press and threatened and harassed journalists throughout the country. The first blow, after the October 12, 1999 coup, Sindh Police tortured journalists in front of Anti-terrorist Court in Karachi $^{25}$. Four journalists were abducted by Sindh Police in Dadu on August 30, $2000^{26}$. Nine Journalists were arrested for covering a protest demonstration of women against Pervez Musharraf during his visit to Hyderabad ${ }^{27}$. Editor of daily Zarb-e-Islam Nisar Ali, Associate editor Mazhar Abbas and M.Irfan were arrested on July 20, 2005. The editor of weekly Friday Special Abudul latif and Abu Shamil were arrested the same day. Editor of weekly Wajood M.Tahir was also arrested in the move against radical publications on July $20,2005^{28}$. The Sindh police detained Rashid Channa, the senior reporter for daily Star Karachi on July 24, $2005^{29}$.Police took the editor Sami Khan, of Magazine Al-Fazl into custody in November $2005^{30}$. Correspondent of Geo TV Mukesh Ropeta and his cameraman Sanjay Kumar were detained by intelligence agencies on March 6, $2006^{31}$.Reporter for daily Kawish Meruddin Mari was arrested on July 2, 2006. More than 180 journalists were tortured by police while they were protesting in Karachi. Twelve journalists were injured ${ }^{32}$.

The government backed political activists, opposition parties, traffickers, land-grabbers, religious parties, individuals, and unknown culprits pressurized the national press throughout Parvez Musharraf's tenure. Representative of daily Ummat Sufi Muhammad

\footnotetext{
${ }^{23}$ Amnesty International, Report, 2014. Retrieved August 23, 2017, from, https://www.am nesty. org.u k / files/pakistan_journalists_300414.pdf

${ }^{24}$ Amir, Latif, interview by Fazal, Hussain, 20 February 2018. Karachi Press Club Karachi, tape recording.

${ }^{25}$ Window-on-Pakistani-Media.1\&2. Accessed on January 2, 2018, from http://www.civiceducation.org/wpcontent/uploads/2010/08/Window-on-Pakistani-Media.pdf

${ }^{26}$ Bureau Report "National” November 19, 1999, Daily Dawn Karachi.

${ }^{27}$ Committee to Protect Journalists. Accessed on January, 4, 2018, from https://cpj.org/2001/03/attacks-on-thepress-2000-pakistan.php

${ }^{28}$ Staff Reporter. "Metropolitan” July 20, 2005

${ }^{29}$ U.S State Department Country report "Freedom of Speech and Press" Accessed on January 4, 2018, from https://www.state.gov/j/drl/rls/hrrpt/2005/61710.htm (2005)

${ }^{30}$ Ibid.

${ }^{31}$ Daily The News. Accessed on January 5, 2018, from https://www.thenews.com.pk/archive/print/12026

${ }^{32}$ Aslam, Rukhsana. "PAKISTAN: Media, politics and the threats to journalists in Pakistan." Pacific Journalism Review: Te Koakoa 21, no. 1 (2015): 177-194.
} 
was killed in Mirpurkhas ${ }^{33}$. According to the Committee to Protect Journalists, he was shot by drug trafficker Ayaz Khatak. Sufi had a reputation for hard line reporting. Sufi Muhammad Khan had filed a story on Khatak's suspected connections with a local prostitute that was published on May 02, 2000 in daily Ummat, the same day the reporter was killed. The killer surrendered to police after 30 minutes of murder. Prior to his death, Sufi had written an article alleging Khatatk on drug trafficking in Badin. He was being threatened to be killed. Sufi was exposed to all threats and that resulted in his death. Police also suspected the Arbab family, which allegedly ran a prostitution ring. After a failed struggle to silent Sufi, the family had filed a defamation case against him and his paper. The American Journalist Daniel Pearl was killed in Karachi ${ }^{34}$. Daniel Pearl, bureau chief of South Asia for The Wall Street Journal, was kidnapped from near the Metropole Hotel in Karachi on January 23, 2002 and then killed. The correspondent of Sindhi newspaper daily Kawish Shahid Somroo was assassinated on October 22, 2002 in front of his house in Mirzapur Mohalla in Kandhkot ${ }^{35}$. The reason behind his murder was his reporting on the abuses committed during the general elections. Representative of daily The Nation Karachi Aziz Sangho was harassed and lamented by the officers of the Karachi Electric Supply Corporation (KESC) ${ }^{36}$, now KE. Journalist Amir Mateen and Kamran Khan were harassed and interrogated in connection with their journalistic work by intelligence agency ${ }^{37}$. Representative of daily Mashriq Nasrullah was kidnapped by a religious group to punish him for his reporting in Hyderabad ${ }^{38}$. Representative of daily Kawish was shot dead in Hyderabad ${ }^{39}$. Cameraman of Sindhi Language TV Kawish Television Network (KTN), Munir Ahmad Sangi was killed in Lardkana. He was covering a gun fight between the Unar and Abro tribes ${ }^{40}$. According to his colleagues Sangi was targeted deliberately for the station's reporting on Jirga. The uncle of deceased journalist was already attacked in this connection. Zubair Ahmad Mujahid, bureau chief of daily Jang in Mirpurkhas was shot dead in the limits of Satellite town police, on November 23, 2007. Ghulam Rasool Birhamani, reporter for Daily Sindhu Hyderabad, was killed on May 9, 2010 in Wahi pandhi near Hyderabad. He was kidnapped a day earlier from his hometown. According to CPJ and Dawn reports, Birhamani was killed for his story of an illegal marriage of a 12 years old girl Najama Lashari with a 22 years old guy Mumtaz Lashari arranged ethnically. Chief reporter of daily Ibrat Sarfaraz Wistro was attacked in Hyderabad by unknown assaulters on July 22, 2010. President of Mirpur Khas Press Club was shot dead for the sack of journalism; he was the Bureau

\footnotetext{
${ }^{33}$ Committee to Protect Journalists. Accessed on January 5, 2018, from https://cpj.org/data/people/sufimohammad-khan/

${ }^{34}$ British Broadcasting Corporation. Accessed on January 7, 2018, from http://news.bbc.co.uk/2/hi/south_asia/1785819.stm

${ }^{35}$ Staff Reporter "Daily Dawn Karachi”. Accessed on January 7, 2018, from https://www.dawn.com/news/62974 (October 22, 2002)

${ }^{36}$ Ibid.

${ }^{37}$ Pakistan Press Foundation. Accessed on January 7, 2018, from

https://www.pakistanpressfoundation.org/government-to-probe-charges-of-harassment-of-journalist/

${ }^{38}$ Daily Dawn “South Asia 'dangerous' region for journalists. Accessed on January 8, 2018 from

https://www.dawn.com/news/359783

${ }^{39}$ Ibid.

${ }^{40}$ Umer Cheema "Not a single killer of 46 journalists found" Geo News. Accessed on January 8, 2018, from

https://www.geo.tv/latest/17001-latest-news
} 
Chief of $A$ waz $T V^{41}$. Wali Khan Baber, reporter for Geo $T V$ was shot dead in Liaqatabad Karachi $^{42}$. Mushtaq Khand, a repoter for Dharti Television Network and newspaper Mehran, was killed in Khairpur on October 7, 2012, when fire was opened by two rival groups during a rally of Pakistan People's Party. Mushtaq Khand was the President of Khairpur Press Club at the time. Shan Dahar, bureu chief for Abb Takk Television in larkhan, was killed in Larkana while filming the illegal sale of drugs on January 2014. Journalist Aurang Zeb was killed in Lalu Ran Wak village; he was the Bureau Chief for Sindhi language TV Kawish. He was punished for his reporting an illegal marriage ${ }^{43}$.Three members of Express TV's crew, Waqas Aziz, Khalid Khan and Ashraf Yusuf were killed in Karachi ${ }^{44}$. Journalist Hamid Mir of Geo TV was fired in Karachi. He was severely injured ${ }^{45}$. Journalist working for Geo TV Aftab Alam was killed outside his house in Karachi ${ }^{46}$. Cameraman for SaamaTV, Taimoor Khan was killed in KDA square $\mathrm{Karachi}^{47}$. He was covering the aftermath of a grenade attack on a police vehicle in North Nazimabad area of Karachi.

The overview affirms that the press and journalists remained under attacks and under pressure in Sindh during the period under study (2000-2017). And actors, including political parties, traffickers, police, religious groups and militants tried their best to confine the freedom press. The ex-presidents of Karachi Press Club Imtiaz Khan Faran and Khursheed Abbasi confirm the pressure on journalists from the above mentioned actors $^{48}$. This situation increase threats to journalists and as a result degrading the freedom of press in the province.

\section{Main stream media vs. local media}

The history of attacks on journalists and media houses reveals that mostly the main stream media has been targeted by interests groups in Sindh. Daily Jang Karachi, daily Dawn Karachi, daily Kawish Hyaderabad, daily Express Karachi, daily Ummat Karachi, Geo TV, AbTakk TV Karachi, Express TV, Dharti TV, Awaz TV and daily Ebrat are among the main affected media houses. The overview also depicts that attacks were made only in the big cities of the province like Karachi, Hyderabad, Larkana and Mirpur Khas. The local newspapers like daily Hamwatan Karachi, daily daily Qyadat Karachi, daily Sindh Hyderabad and so on and their affiliated journalists remained safe. The founder of the Jang Group of Newspapers Mir Khalil URehman in an interview confessed that

${ }^{41}$ Daily The News. Accessed on January 8, 2018, from https://www.thenews.com.pk/archive/print/273401mirpurkhas-press-club-president-shot-dead

${ }^{42}$ Junaid Ikram "2011 Saw 12 Journalists killed in Pakistan" daily Dawn. Accessed on January 9, 2018, from https://www.dawn.com/news/684514

${ }^{43}$ Committee to Protect Journalists. Accessed on January 11, 2018, from https://cpj.org/data/people/aurangzebtunio/

${ }^{44}$ Daily Express Tribune. Accessed on January 15, 2018, from https://tribune.com.pk/story/660249/3-stafferskilled-in-attack-on-express/

${ }^{45}$ Daily Dawn Karachi. Accessed on January 18, 2018, from https://tribune.com.pk/story/660249/3-stafferskilled-in-attack-on-express/

${ }^{46}$ Geo TV. Accessed on January 19, 2018, from https://www.geo.tv/latest/5866-senior-journalist-aftab-alamgunned-down-in-karachi

${ }^{47}$ Ali,Imtiaz. "Daily Dawn Karachi." Accessed on January 23, 2018, from tps://www.dawn.com/news/1314347

${ }^{48}$ Imtia Faranand and Khursheed, Abbasi, interview by Fazal Hussain, 14 February 2018, Karachi Press Club

Karachi, tape recording. 
political actors were pressuring the press for more space and coverage and Jang was the most affected media house due to its largest circulation ${ }^{49}$. The most influential media houses and the investigative journalists stay on the target and that is the usual practice in the province of $\operatorname{Sindh}^{50}$.

\section{Survey regarding threats to journalists in Sindh}

Survey method was used to get ground realities regarding threats to journalists in the province of Sindh consulting the journalist's community. A sample of 150 working journalists was selected on the basis of Snowball technique. One hundred and forty four questionnaires were found completed from all aspects and the data was analyzed, using statistical tools i-e tables and pie-chats under Likert's Summative Scale.

Interviews of veteran journalists and post bearers of the journalist's organizations like Federal Union of Journalists (PFUJ), Karachi Union of Journalists (KUJ), Karachi Press Club (KPC), Hyderabad Press Club (HPC) and Larkana Press Club (LPC) were conducted to generalize the results and reach the ground realities behind the threats to journalists in the province of Sindh. In this respect eleven prominent and active journalists were consulted and interview were recorded after their permission.

Table: 1

Journalists facing threats in the line of their professional duties (percentage) $(n=144)$

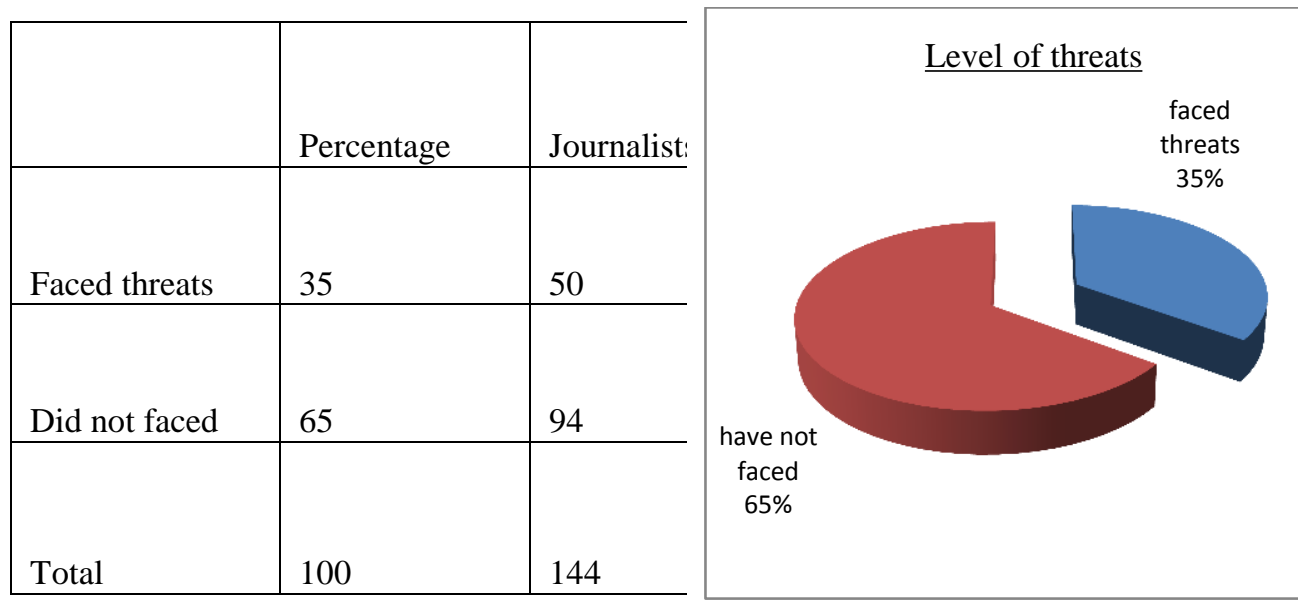

${ }^{49}$ Tahir, Mahsood, eds., "Shafat avr Tashadud” (Karachi: Laraib Printing Press Urdu Bazar, 1990), 96-99).

${ }^{50}$ Khaliq, Chandeo, interview by Fazal, Hussain, 24 February 2018. Hyderabad Press Club Hyderabad, tape recording. 
The table and figure 1 show that majority of journalists $(65 \%)$ are not facing threats in connection with their journalistic work while $35 \%$ of journalists are confronting threats. The data shows that threat is present in the profession.

Table: 2

Nature of threats, journalists are facing in connection with the profession (percentage $)(\mathbf{n}=\mathbf{5 0})$

\begin{tabular}{|l|l|l}
\hline & Percentage & Qty \\
\hline killing & 26 & 13 \\
\hline kidnapping & 0 & 0 \\
\hline Dire Consequences & 74 & 37 \\
\hline Total & 100 & 50 \\
\hline
\end{tabular}

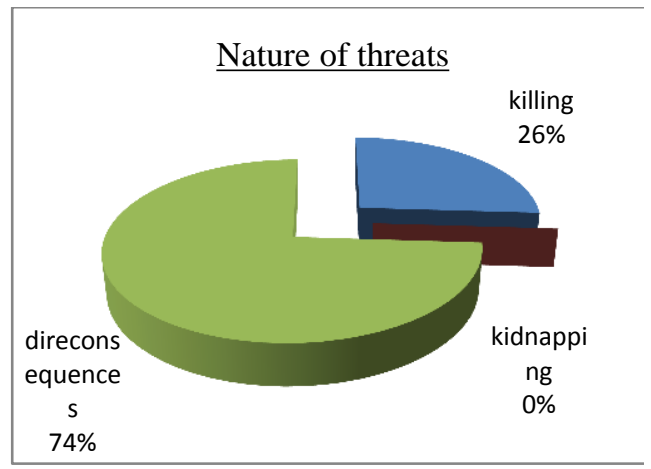

The table \& figure 2 reveal that most (74\%) of the threats are given in the form of "Dire Consequences". The killing follows with $26 \%$ while "Kidnapping" acquires $0 \%$ in the table. The data shows that journalist are receiving threats in the for kidnapping.

Table: 3

The target of the threatening actors (percentage) $(n=50)$

\begin{tabular}{|l|l|l|}
\hline & percentage & quantity \\
\hline Journalist & 63 & 31 \\
\hline Family & 0 & 0 \\
\hline Both & 37 & 19 \\
\hline Total & 100 & 50 \\
\hline
\end{tabular}

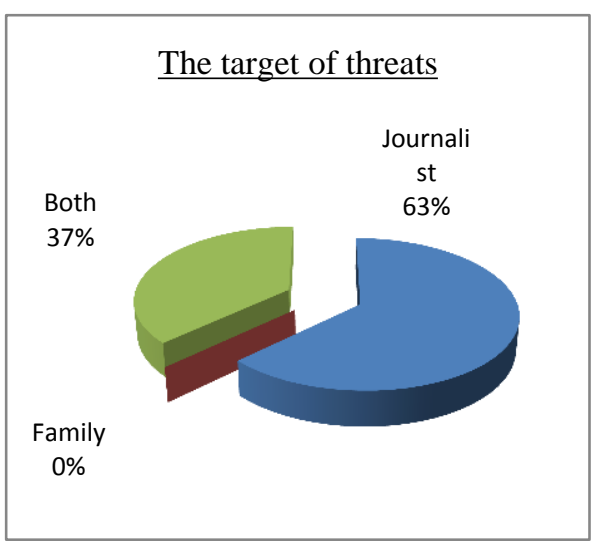


Table and figure 3 indicate that threats are mostly $(63 \%)$ directed towards the journalists while $37 \%$ goes to both the journalists and their families where as no threat is pointed to the family alone. This trend of threatening denotes that journalists and their families are on the target of actors pressurizing journalists for their professional duties.

Table: 4

Actors behind the threats (percentage) $(n=50)$

\begin{tabular}{|l|l|l|}
\hline Actors & percentage & Qty \\
\hline The governing Party & 4 & 2 \\
\hline The Opposition parties & 7 & 3 \\
\hline Establishment & 4 & 2 \\
\hline Law enforcement agencies & 11 & 5 \\
\hline Traffickers & 0 & 0 \\
\hline Land grabbers & 15 & 8 \\
\hline Militants & 11 & 5 \\
\hline Religious Groups & 4 & 2 \\
\hline Social Activists & 4 & 2 \\
\hline Economical Interest Groups & 4 & 2 \\
\hline Individuals & 15 & 8 \\
\hline Unknown & 21 & 11 \\
\hline Total & 100 & 50 \\
\hline
\end{tabular}




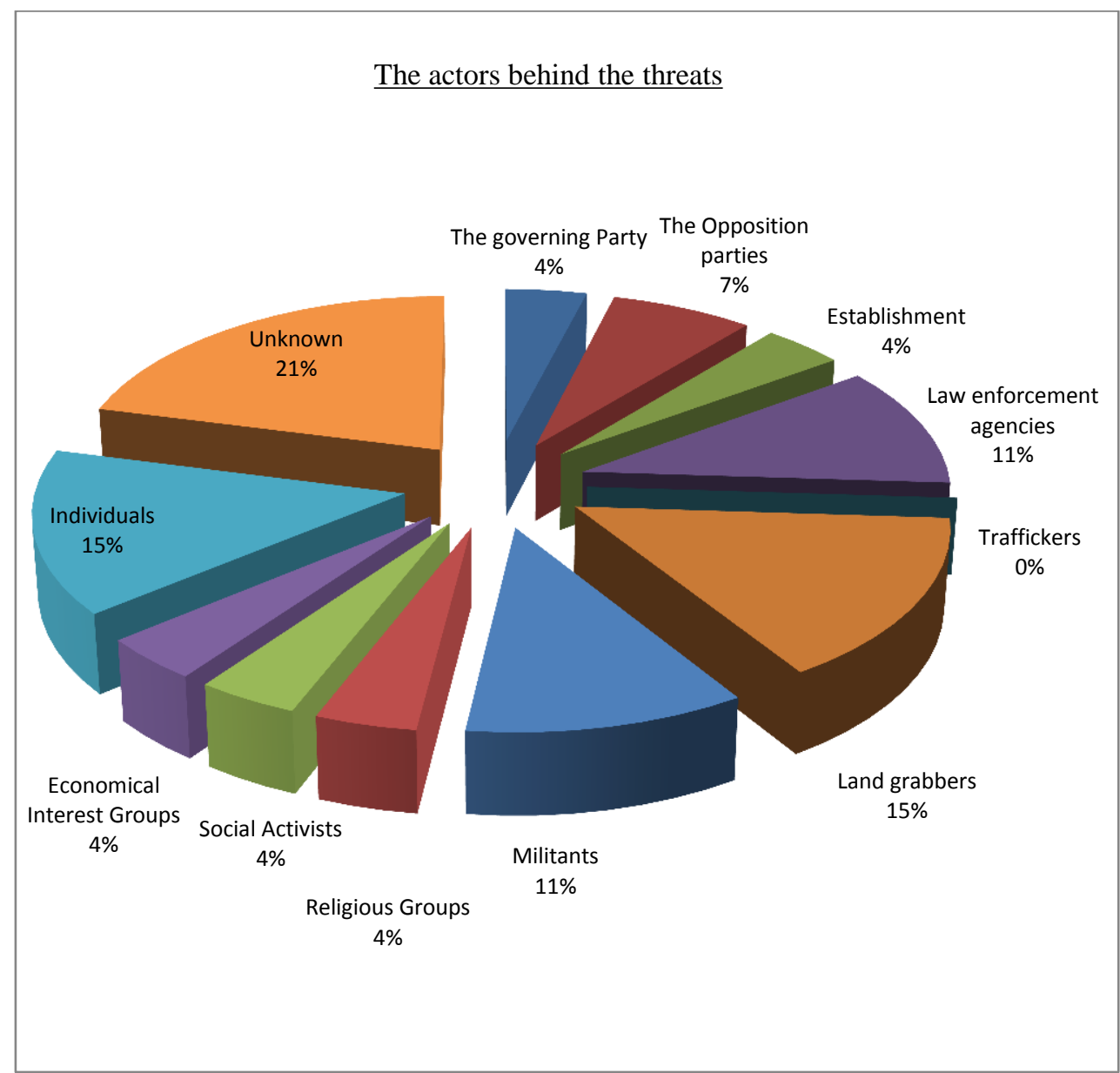

Table and figure 4 show that most $(21 \%)$ of the actors behind the threats are unknown seconded by the land grabbers and individuals with $15 \%$. Law enforcement agencies and militants are on the third stage with $11 \%$ of threatening actors whereas opposition political parties are on forth number attaining a percentage of 7 . The governing parties, establishment, economical interest group, religious groups and social activist groups are on the fifth stage with $4 \%$ while no threat from traffickers have been received by journalists under study in Sindh. 
Table: 5

Trend to file complain against threats received (percentage) $(n=50)$

\begin{tabular}{|l|l|l|}
\hline & Percentage & Qty \\
\hline Registered Complaint & 37 & 18 \\
\hline Didn't Complain & 63 & 32 \\
\hline Total & 100 & 50 \\
\hline
\end{tabular}

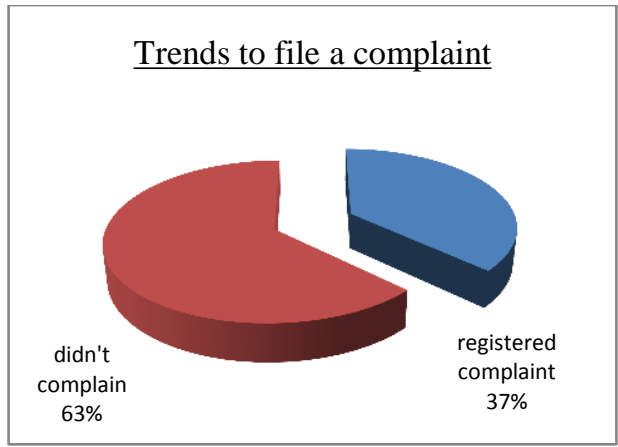

Table and figure 5 illustrate that only $37 \%$ of journalists have gone with a complaint after they received threats for their journalistic works where most of the respondents (63\%) have not registered any complaint even after they confronted threats.

Table: 6

Where the complaints are filed (percentage) $(n=18)$

\begin{tabular}{|l|l|l|}
\hline & Percentage & qty \\
\hline Police & 43 & 8 \\
\hline Court & 0 & 0 \\
\hline Employer & 0 & 0 \\
\hline Editor & 57 & 10 \\
\hline Total & 100 & 18 \\
\hline
\end{tabular}

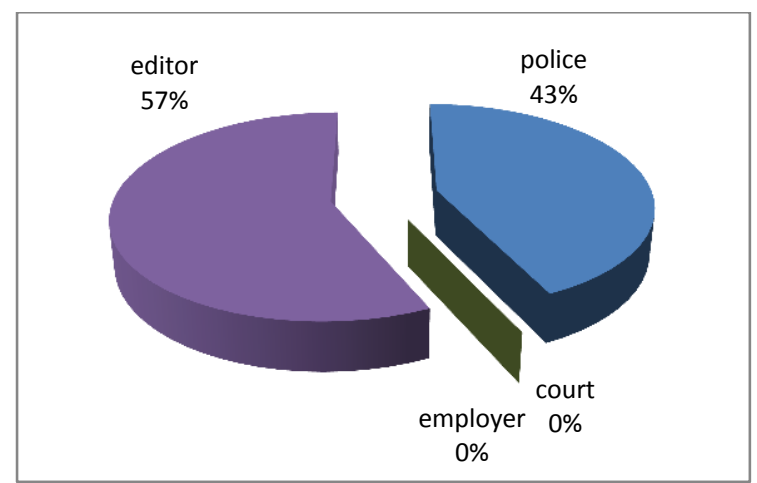

Table and figure 6 show that most of the respondents (57\%) go to register complaints with the editor against the threats while $43 \%$ of the journalists registered complaints with police. The data indicates that there is no trend to register complaints with the court or the employer. 
Table: 7

Strength of responses to complaints (Percentage) $n=18$

\begin{tabular}{|l|l|l|}
\hline & Percentage & Qty \\
\hline Responded & 57 & 10 \\
\hline Didn't respond & 43 & 8 \\
\hline Total & 100 & 18 \\
\hline
\end{tabular}

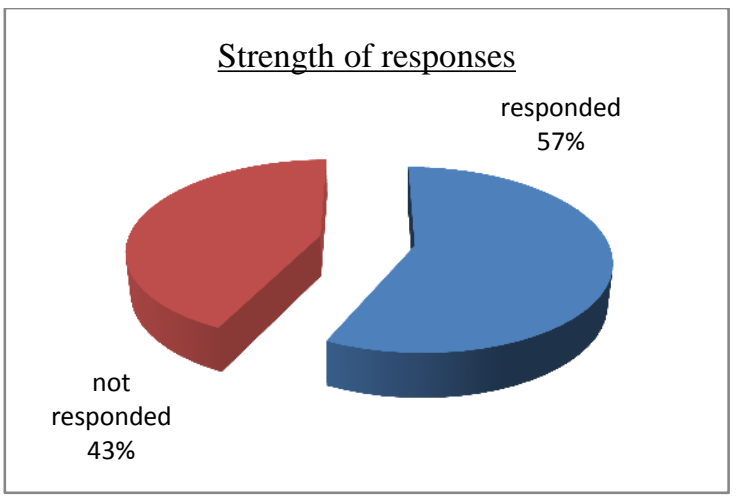

Table and figure 7 divulge that the responding fashion is better as $57 \%$ of the complaints are responded while $43 \%$ could not meet a hope of response.

Table: 8

Level of satisfaction against the complaints (percentage) $n=18$

\begin{tabular}{|l|l|l|}
\hline & Percentage & Qty \\
\hline Satisfied & 57 & 10 \\
\hline Not satisfied & 43 & 8 \\
\hline Total & 100 & 18 \\
\hline
\end{tabular}

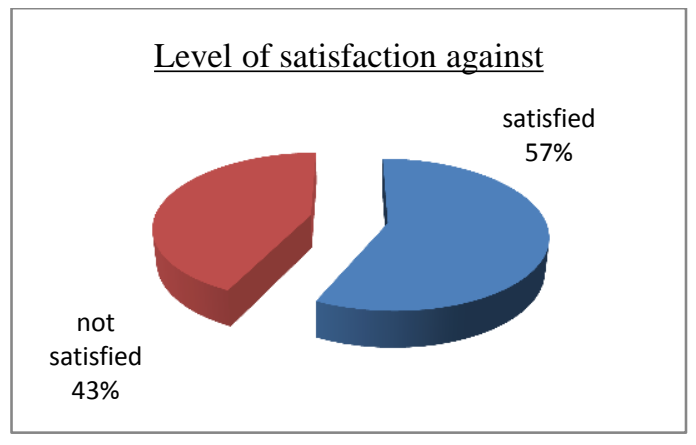

Table and figure 8 reveal that level of satisfaction is hopingly more $57 \%$ than no satisfaction which denotes $43 \%$ calculating the respondent's perception. The result indicates that complaints are considered and resolved. This trend is encouraging faced and needs to be advocated for $100 \%$ results. 
Table: 9

Effects of threats on the objectivity of journalistic work (percentage) $\quad n=18$

\begin{tabular}{|l|l|l|}
\hline & Percentage & Qty \\
\hline Affected & 47 & 8 \\
\hline Didn't affect & 53 & 10 \\
\hline Total & 100 & 18 \\
\hline
\end{tabular}

The effects of threats on the working capacity
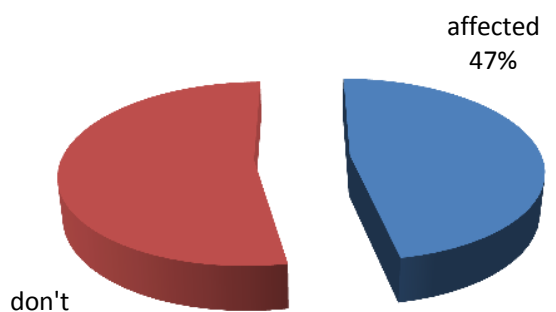

affect

$53 \%$

Table and figure 9 illustrate most $(53 \%)$ of the respondents point out no effect of threats on the objectivity of their journalistic work while lesser (47\%) respondents admitted bad effects on the objectivity of professional performances. But the data affirms the very existence of the effects on the objectivity of journalistic work.

Table: 10

The level of Self-Censorship (percentage) $\quad n=144$

\begin{tabular}{|l|l|l|}
\hline & Percentage & Qty \\
\hline Exercised & 26 & 37 \\
\hline Partially & 39 & 56 \\
\hline Not at all & 35 & 51 \\
\hline Total & 100 & 144 \\
\hline
\end{tabular}

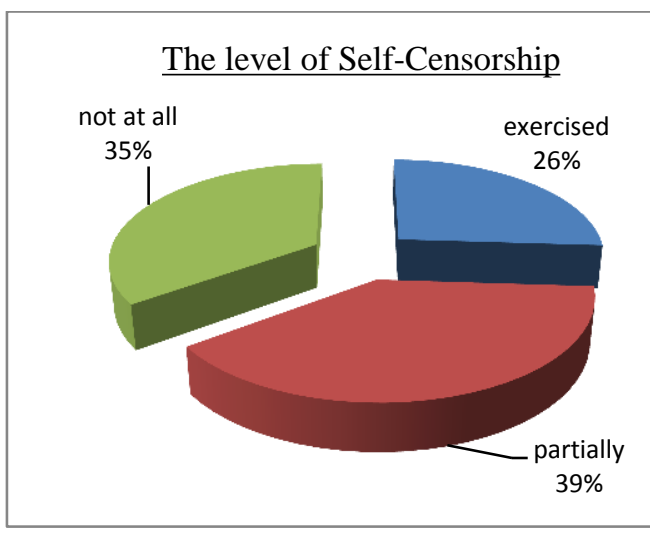

Table and figure 10 reveal that most of the respondents exercise self-censorship for their journalistic work. Majority (39\%) of the journalists partially follow the self-censoring rule while $26 \%$ respondents admitted full subjugation where as $35 \%$ of the journalists don't use the cuts in their stories. 
Table: 11

Motive behind the self-censorship (percentage) $\mathbf{n = 9 3}$

\begin{tabular}{|l|l|l|}
\hline & $\begin{array}{l}\text { Percent } \\
\text { age }\end{array}$ & Qty \\
\hline $\begin{array}{l}\text { To avoid judicial } \\
\text { constraints }\end{array}$ & 43 & 40 \\
\hline $\begin{array}{l}\text { To avoid the anger of } \\
\text { employer }\end{array}$ & 22 & 20 \\
\hline To avoid the threats & 35 & 33 \\
\hline Total & 100 & 93 \\
\hline
\end{tabular}

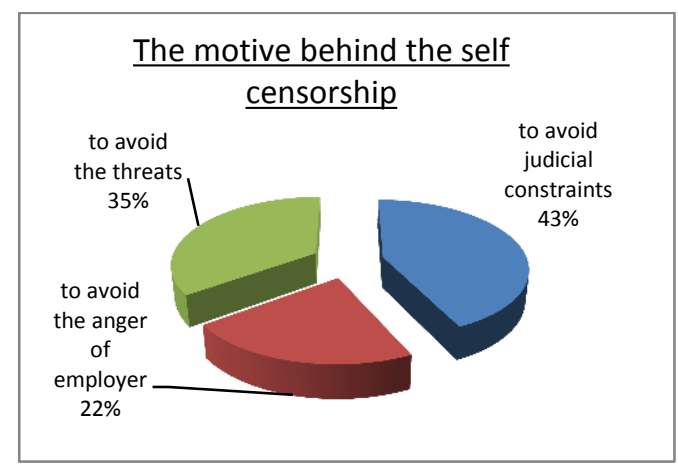

Table and figure 11 show that motive for self-censorship is mostly (43\%) to avoid judicial constraints followed by $35 \%$ to avoid the threats where as $22 \%$ is to avoid the anger of the employer.

Table: 12

Level of satisfaction against the self-censorship (percentage) $n=93$

\begin{tabular}{|l|l|l|}
\hline & percentage & Qty \\
\hline fully satisfied & 22 & 21 \\
\hline partially & 68 & 63 \\
\hline not at all & 10 & 9 \\
\hline Total & 100 & 93 \\
\hline
\end{tabular}

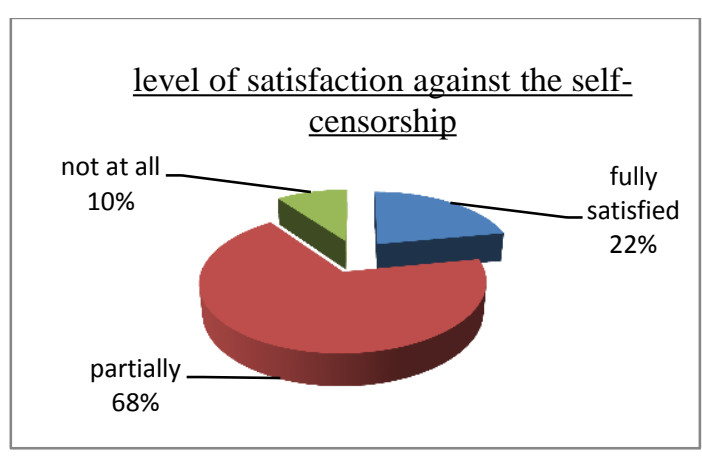

Table and figure 12 explain that after applying the Self-Censorship, most $(68 \%)$ of the respondents are satisfied while $22 \%$ feel partial satisfaction whereas only $10 \%$ of the respondents are not satisfied even after censoring their journalistic work. 
Table: 13

Safety level for working journalists (percentage) $\quad n=144$

\begin{tabular}{|l|l|l|}
\hline & Percentage & Qty \\
\hline Completely safe & 2 & 3 \\
\hline Partially safe & 19 & 27 \\
\hline Unsafe & 77 & 111 \\
\hline Have no idea & 2 & 3 \\
\hline Total & 100 & 144 \\
\hline
\end{tabular}

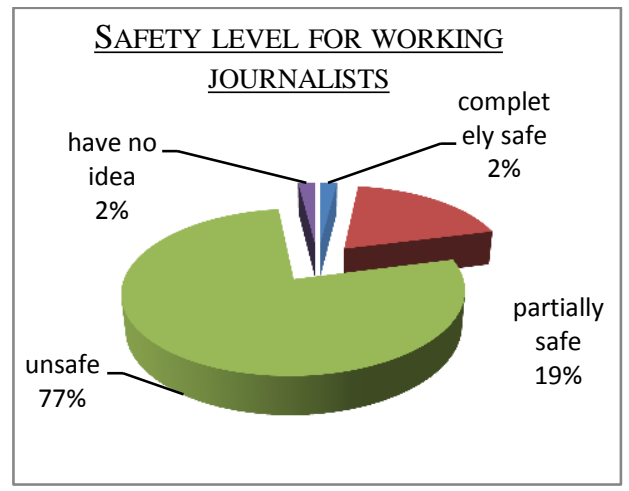

Table and figure 13 illustrate a very vast majority (77\%) of the respondents feels that journalists are completely unsafe for their journalistic work while $19 \%$ are of the opinion that journalists are partially unsafe in their profession. A very little (2\%) of the respondents affirm that the environment is safe for working journalists where as $2 \%$ of the respondents mark that they have no idea regarding the safety conditions for journalists.

Table: 14

Level of the pressure: working journalists are facing (percentage) $n=144$

\begin{tabular}{|l|l|l|}
\hline & $\begin{array}{l}\text { Percen } \\
\text { tage }\end{array}$ & Qty \\
\hline $\begin{array}{l}\text { Working under full } \\
\text { pressure }\end{array}$ & 39 & 56 \\
\hline Partly under pressure & 51 & 74 \\
\hline Not under pressure & 7 & 10 \\
\hline Have no Idea & 3 & 4 \\
\hline Total & 100 & 144 \\
\hline
\end{tabular}

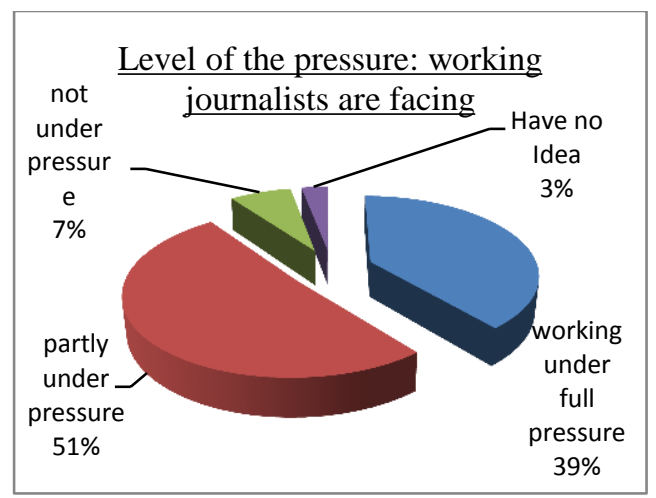

Table and figure 14 reveal that journalists are working under pressure in the province. Most $(51 \%)$ of the respondents affirm that journalists are under partial pressure while 39\% assert that working journalists are in a state of full pressure in respect to their professional duties. Only $7 \%$ of the respondents are sure that journalists are not under any pressure in regards to their journalistic performances while $2 \%$ of the respondents have no idea about the pressure on journalists in connection with the profession. 


\section{Conclusion}

The press and journalists remains under pressure and are exposed to threats in Sindh and the working environment is not favorable for an institutionalized journalism. The presence of threats $(35 \%)$ indicates that journalists are confronting fear in the region for their journalistic performance. Same is the condition with the families of journalists as $37 \%$ have affirmed receiving threats. The more drastic situation rests here that the $21 \%$ of the actors behind the threats are unknown, $15 \%$ each from land grabbers and individuals. The governing and opposition political parties, the law enforcement agencies, social , religious, militant and economical interests groups are all involved in threatening and pressurizing journalists for their professional activities. The other aspect is that $39 \%$ of the journalists facing full while $51 \%$ are confronting partial pressure. This picture of media in Sindh reveals that media professionals are living in a state of war where $77 \%$ journalists feel unsafe.

Media professionals are balancing and handling the situation applying self-censorship on their journalistic jobs, as $26 \%$ exercise full self-censorship and 39\% partially. The ill aspect of the scenario is that $43 \%$ of the journalists use the hammer of self-censorship to avoid judicial and legal constraints. This aspect of the situation is the most disappointing for the freedom of press and expression.

The trend not to register complaints $(63 \%)$, discloses the fear and despair of journalists although the response rate is $57 \%$ and satisfaction scores the same. Most $(57 \%)$ of the journalists go to editors for complaints against threats.

The review of the events and literature exploration also corroborate the unfavorable situation for media persons in Sindh. The killings, injuring, threatening, pressurizing and arresting of journalists adds hindrances for the journalist's community. It is very clear to say that the governmental, political, social and media owner's behavior is not hoping for a free press in the province of Sindh.

\section{Recommendations}

The whole media theater in Sindh needs a lot of attention in all aspects with special emphases on the security measures. The study recommends the following certain directives to for free and the media persons from the fear inculcated in them and to assure the convening of true, impartial and objective information to the citizens not paralyzed by Self-Censorship or enshrined in the folds of fear of adverse responses.

Rule of law should be insured to develop a sense of safety in journalists and Job security should be secured by law to lesser the fear for unemployment, prevailing in media persons. Measures are needed to avoid the threatening actors from being a sword on the necks of the watchdogs. For the purpose, media campaigns and regulations will be effective. Training should be arranged to encourage and educate journalists for their rights and responsibilities. Research is needed to explore all the aspects deteriorating the media landscape in the province of Sindh. 